\title{
Rubella-Specific IgM in Reinfection and Risk to the Fetus
}

\begin{tabular}{|l|l|l|}
\hline M. & Mali & Zolti $^{\mathrm{a}}$ \\
\hline Z. & Zion & Ben-Rafael $^{\mathrm{a}}$ \\
\hline D. & David & Bider $^{\mathrm{a}}$ \\
\hline S. & Shlomo & Mashiach $^{\mathrm{a}}$ \\
\hline A. & Alice & Fogel $^{\mathrm{b}}$ \\
\hline
\end{tabular}

${ }^{a}$ Department of Obstetrics and Gynecology and ${ }^{b}$ Department of Virology, The Chaim Sheba Medical Center and Sackler School of Medicine, Tel Aviv University, Tel Hashomer, Israel

\section{Key Words}

Fetus

Immunoglobulin

Rubella

\section{Abstract}

A case of reinfection with the wild rubella virus in the 8th gestational week is reported. The patient had preexisting hemagglutination inhibition antibodies of low titer following immunization with rubella vaccine. Reinfection was accompanied by clinical symptoms and the presence of rubella-specific immunoglobulin $\mathrm{M}$ (IgM) of high titer. Following termination of pregnancy no rubella virus could be isolated from the fetal tissues and the fetal blood contained no specific IgM antibodies. These results should encourage the use of cordocentesis before decision on interruption of pregnancy.

Dr. Mati Zolti, Department of Obstetrics and Gynecology, The Chaim Sheba Medical Center, Tel Hashomer 52621 (Israel) Introduction

Rubella reinfection during pregnancy is generally not considered teratogenic [1]. It is not clear, however, whether reinfection accompanied by clinical symptoms and the appearance of specific immunoglobulin $\mathrm{M}(\mathrm{IgM})$ antibodies can affect the fetus [2].

We present a case of reinfection at 8 weeks' gestation with clinical signs and a high titer of specific IgM. Pathological examination of the aborted fetus at 14 weeks' gestation revealed no signs of infection with the rubella virus.

\section{Case Report}

The patient was a 27 -year-old woman, who had received two rubella vaccinations, the ñrst at the age of 12 years and the second 13 years later, after she was found to be rubella-seronegative. No subsequent serological tests were performed until she was 6 weeks pregnant and her 11-monthold child developed a rash which was suspected to be rubella. Tests of maternal blood samples showed low-titer immunoglobulin $\mathrm{G}$ (IgG) antibodies, but were negative for specific rubella IgM (table 1). Two weeks later she developed a fever $\left(38^{\circ} \mathrm{C}\right)$ and general malaise, but no skin rash. Subsequent blood samples showed a significant rise of IgG antibodies and a high titer of specific IgM. Serological examination of the 11-month-old son confirmed recent rubella infection. Maternal serological tests for other vimses excluded recent cytomegalovirus or Epstein-Barr vims infection. The test for rheumatoid factor was negative. 
The combination of clinical symptoms and high rubella-specific IgM led to the decision to terminate this pregnancy in the 14th week by intra-amniotic injection of prostaglandin F2 $\alpha$ - The fetal blood obtained from the heart following expulsion was positive for rubella IgG, but had no IgM antibodies. The fetal tissues and placenta showed no rubella vims, when tested by the interference method in monkey kidney cell cultures [3].

Discussion

This case illustrates one of several new diagnostic problems which arise following mass immunization with rubella vaccine. It is well known that the available rubella vaccines licensed so far immunize only about $95 \%$ of seronegative subjects [4].

Our patient apparently failed to seroconvert following her first vaccination. The second immunization induced a low antibody response. Following infection of her 11-month-old child with wild rubella virus, she experienced reinfection, accompanied by clinical symptoms. This clinical event resulted also in the appearance of rubella-specific IgM, which, in contrast to similar cases reported by others, was of high titer [5]. Since the tests for cytomegalovirus, Epstein-Barr virus, IgM and rheumatoid factor were negative, the decision on termination of pregnancy seemed justified.

Rubella IgM

185

Table 1. Results of antibody tests in serial blood samples

SampleDate Rubella tests' Tests for other factors

No.

HI IgM neutralization RF EBV CMV

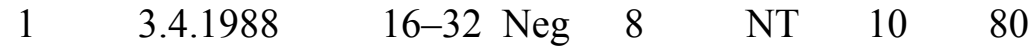

$\begin{array}{lllllll}14.4 .1988 & 64 & \mathrm{Neg} & \mathrm{NT} & \mathrm{NT} & \mathrm{NT} & \mathrm{NT}\end{array}$

$22.4 .1988 \quad 2,048+++\quad>128$ NT $\quad$ NT NT

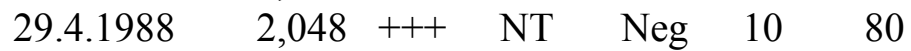

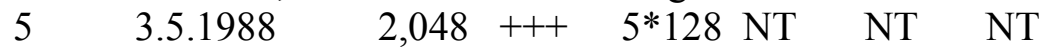

$\begin{array}{lllllllll}6 & 18.5 .1988 & 2,048 & ++ & >128 \mathrm{NT} & \mathrm{NT} & \text { NTChild } & 1.5 .1988 & 256\end{array}$

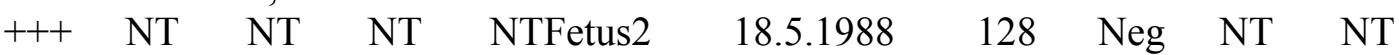

NT NT

Sample No. 1-6 represent maternal blood. $\mathrm{HI}=$ Hemagglutination inhibition; $\mathrm{RF}=$ rheumatoid factor; $\mathrm{EBV}=$ Epstein-Barr virus; $\mathrm{CMV}=$ cytomegalovirus; $\mathrm{Neg}=$ negative; $\mathrm{NT}=$ not tested. 1 Reciprocal of titer.

2 Day of pregnancy termination.

Tests on the aborted fetus, however, suggested that this decision was premature. No virus was isolated from either the placenta or fetal tissues, although infection at this early gestational age is usually accompanied by a high isolation rate from fetal tissues [6]. The recent introduction of percutaneous umbilical blood sampling (cordocentesis) $[7,8]$ seems to offer a better diagnostic approach to rubella infection in pregnancy. In our case the fetal blood sampling was performed too early to be significant. The test for specific IgM in the cord blood at 22 gestational weeks would have provided important information and probably have spared an unnecessary termination of pregnancy.

References

Cradock-Watson JE, Ridehalgh MKS, Anderson MJ, Pattison JR: Outcome of asymptomatic infection with rubella virus during pregnancy. J Hyg Cambridge 1981;87:147-154. 
Miller CL, Miller E, Waight PA: Rubella susceptibility and the continuing risk of infection in pregnancy. Br Med J 1987,294: 1277-1278.

Parkman PD, Buescher EL, Artenstein MS: Recovery of rubella virus from army recruits. Proc Soc Exp Biol Med 1962;11l:225- 230.

Plotkin SA, Farquar JD, Ogra PL: Immunologic properties of RA-27/3 rubella virus vaccine. A comparison with strains presently licensed in the United States. JAMA 1973;225:585-590. Morgan-Capner P, Hambling MH, Coleman TJ, et al: Detection of rubella-specific IgM in subclinical rubella reinfection in pregnancy. Lancet 1985;i:244-246.

Cradock-Watson JE, Miller E, Ridehalgh MKS, Ho-Terry L: Detection of rubella virus in fetal and placental tissues and in the throats of neonates after serologically confirmed rubella in pregnancy. Prenat Diagn 1989;9:91-96.

Daffos F, Forestier F, Grangeot-Keros L, et al: Prenatal diagnosis of congenital rubella. Lancet 1984;ii. 1-3.

Morgan-Capner P, Rodeck CH, Nicolaides K, Cradock-Watson JE: Prenatal diagnosis of rubella. Lancet 1984;ii:343. 